\title{
Lizzie Collingham, The Hungry Empire: How Britain's Quest for Food Shaped the
}

Modern World. London: The Bodley Head, 2020, $\mathrm{x}+400$ pp. ISBN: 9781847922700 , price: EUR 25.00 (paperback).

Does food matter to empire? In The Hungry Empire, Lizzie Collingham wrestles with this question, arguing that food was a driving force that shaped the British Empire from its origins. Spanning four centuries and continents, this sweeping account shows forcefully how the demand for food shaped new connections with far-flung places to supply England, later Britain, with an ever-increasing portion of its food supply. Elegantly written with a public audience in mind, the book consists of twenty chapters-but these are better described as vignettes, taking as their starting point a meal in a particular time and place, and situating these within the wider political, cultural, and social currents of empire.

The book's twenty chapters proceed in roughly chronological order and cover a wide range of geographies, focusing on the British Isles, the Americas, Africa, and South Asia. The first chapter, focused on the sixteenth century, argues that demand from the English navy led to the development of new trade networks in Newfoundland cod, which laid the groundwork for later imperial expansion. The next five chapters focus on the seventeenth century, when England, later Britain, was a marginal player on the world imperial stage.

Chapter 7-10 spotlight the transformations of Britain's eighteenth century empire, focusing in particular on how changing rural diets in England were linked to the country's nascent 'industrialization'; the growth of the provisions trade; and how Britain's American colonies were sustained by rice and rum produced by enslaved people from West Africa. Chapters eleven to fourteen take us into the nineteenth century, where Collingham examines subjects as diverse as the Opium Wars, European migration to New Zealand, the meanings of processed foods for British colonists, and the mobility of European provisions to the Pacific. The final part of the book, covering six chapters, traverses time and space, examining: tropical plantations in Guyana; wheat production in America and regions conquered through settler colonialism; the incorporation of imported foods into working class diets in Britain; the impact of the empire on subsistence farming in Kenya; Britain's dependency on its empire during the Second World War; and, finally, the significance of 'plum pudding' which incorporated ingredients from across the empire, and itself shaped eating practices in far-flung colonies.

The above themes certainly make the book relevant to Southeast Asianists. However, the book's coverage of the geographical, political, cultural, and social category that we today call Southeast Asia is extremely thin. Rather, Collingham excels in her focus on nineteenth century South Asia, the subject of her 
previous book Imperial Bodies. The few scattered references to Southeast Asian geographies use somewhat confusing terminology, such as a "Chinese Malay" (p. 237) and the "Indian archipelago" (p. 262), but without making clear whether these are analytical or source categories. One wonders, then, if the omission of this region - the history of which is characterized by the trade in valuable food products, British colonialism, and the influx of large communities from South Asia and China - has not been a missed opportunity in a book that deals with culinary globalization.

Even though aimed at a public audience, the book occasionally engages in selective historiographical debates. In Chapter 11, Collingham ventures into controversial terrain about the Opium Wars. But her attempt to add some nuance to the debate could be strengthened by including Chinese historiographical perspectives. This chimes with the general trend of the book to focus more on Britain-centred perspectives, whether that be in Britain itself, or its colonizers abroad. This reader would have liked to hear more of the perspectives of 'colonized' people. How did food matter, or not matter, for these people, who far outnumbered the tiny minority of British colonists in almost every reach of its empire? This would add layers of richness and nuance to our understanding of the lived experiences of colonialism, and why and how food helps historians to narrate these stories.

Overall, however, these points do not detract from Collingham's aim to show how food created myriad connections between British colonies, as well as between those colonies and Britain. The book comes at a fascinating juncture in the politics of imperial nostalgia in contemporary Britain. It is highly engaging, accessible, and is sure to provoke lively debates around the dinner table.

\author{
Kathleen Burke \\ University of Toronto, Toronto, Ontario, Canada \\ Kathy.burke@mail.utoronto.ca
}

